\title{
Main Reasons for the Transformation of Mandatory Hungarian Private Pension Funds
}

\author{
Peter Novoszath \\ National University of Public Service, Budapest, Hungary \\ Novoszath.Peter@uni-nke.hu
}

\section{ABSTRACT}

The main purpose of writing this paper was to provide a clear summary of the main facts and motives of restructuring the financing of Hungarian social security system which has been in process since 2010. One of the main lessons learned from the development of the Hungarian pension system so far is that the mandatory private pension funds working on the basis of a funded scheme were not able to solve the problems whose solution they were established for. In addition, they caused further problems.

Keywords: budgetary deficit, EU's Stability and Growth Pact, Hungarian pension reform, mandatory private pension system, public debt

JEL: H55, H62, H63, H75

\section{Introduction}

In addition to determining the effectiveness of Hungarian mandatory private pension funds there was another important objective of this study to clarify the extent of effectiveness of the system in solving the demographic problem. The analysis of the demographic problem can be found in Barr (1979, 2002, 2012) and European Commission $(2010,2012,2014,2016)$ studies. According to the previous approach it is commonly referred to funded pension schemes as safer than the PAYG mechanism. In contrast, today it is widely known that the financial and capital market crisis negatively influenced the extent of interest rates and various social security funds' financial stability and regression of the yields. Which had serious consequences particularly for the multi-pillar pension schemes and pension assets return.

Only five countries had positive returns on the pension funds between 2008 and 2011, while in others, by contrast, a significant decrease occurred (Natali \& Stamati, 2013). It is striking, however, that between 2002 and 2007, in five countries, the United Kingdom (0.3\%), Czech Republic (1.3\%), Hungary (2.1\%), Austria (2.2\%) and Germany (2.6\%) the pension funds had only relatively low 
return, the average net rate of return was of less than 3\% could be achieved. The extremely greatest negative impact was in 2008, then a partial recovery period followed and then once again negative returns associated became characteristic of market uncertainty in 2011. The most adverse effects occurred in those countries where in investment portfolio of pension funds there was an outstanding weight (30\% or greater ratio) of listed shares in stock exchange.

Therefore pension funds produced the worst yields in Ireland $(-35.7 \%)$, Bulgaria (-32.3\%), Belgium (-22.3\%), Estonia (-23.1\%) and Hungary (-21.7\%) in 2008. These processes worsened significantly with demographic problems, thereby making the pension system's long-term unsustainable (European Commission, 2012).

Table 1: The development of the pension funds' actual net rate of return in some EU countries

\begin{tabular}{|l|c|c|c|c|c|c|}
\hline & $\begin{array}{c}\text { Average } \\
\text { return } \\
\text { 2002-2007 }\end{array}$ & 2008 & 2009 & 2010 & 2011 & $\begin{array}{c}\text { Total return } \\
\text { 2008-2011 }\end{array}$ \\
\hline Austria & 2.2 & -14.4 & 7.3 & 3.7 & -6.0 & -10.0 \\
\hline Belgium & 4.7 & -22.3 & 13.4 & 4.4 & -4.6 & -12.0 \\
\hline Bulgaria & 4.6 & -32.3 & 5.6 & 2.5 & -3.0 & -28.0 \\
\hline $\begin{array}{l}\text { Czech } \\
\text { Republic }\end{array}$ & 1.3 & -1.5 & -0.6 & -1.2 & 0.5 & -2.0 \\
\hline Denmark & 3.9 & 5.1 & 1.2 & 7.1 & 12.1 & 27.0 \\
\hline Estonia & 6.5 & -23.1 & 13.2 & 2.5 & -7.9 & -17.0 \\
\hline Finland & 4.3 & -19.7 & 14.0 & 7.1 & -4.4 & -6.0 \\
\hline Greece & $n .2$. & 2.3 & 0.3 & -7.8 & -5.6 & -10.0 \\
\hline $\begin{array}{l}\text { The } \\
\text { Netherlands }\end{array}$ & 4.1 & -17.3 & 11.5 & 8.8 & 8.2 & 8.0 \\
\hline Ireland & -7.3 & -35.7 & $:$ & $:$ & $:$ & $:$ \\
\hline Latvia & $:$ & $:$ & $:$ & 18.6 & -6.6 & 10.0 \\
\hline Poland & 9.4 & -17.3 & 8.9 & 7.2 & -9.1 & -12.0 \\
\hline Luxembourg & 10.4 & -11.3 & 6.5 & 0.7 & -2.2 & -7.0 \\
\hline Hungary & 2.1 & -21.7 & 12.8 & 4.2 & -0.5 & -8.0 \\
\hline Germany & 2.6 & 0.5 & 3.9 & 3.4 & $:$ & 7.0 \\
\hline Italy & $:$ & -5.3 & 5.3 & 1.2 & -2.8 & -1.0 \\
\hline Portugal & 4.4 & -13.2 & 11.6 & -3.0 & -7.3 & -12.0 \\
\hline Romania & $:$ & 10.7 & 10.3 & 8.5 & -0.3 & 32.0 \\
\hline Slovakia & -0.1 & -8.9 & 1.0 & 0.0 & -3.8 & -11.0 \\
\hline Slovenia & -1.0 & -5.4 & 4.2 & 1.8 & -1.8 & -1.0 \\
\hline Spain & $:$ & -9.9 & 6.9 & -2.2 & -2.2 & -7.0 \\
\hline $\begin{array}{l}\text { United } \\
\text { Kingdom }\end{array}$ & 0.3 & -0.9 & -0.9 & -2.1 & -2.5 & -6.0 \\
\hline
\end{tabular}

Source: Natali \& Stamati (2013, p. 16) 
Due to the protracted crisis in the period 2008 to 2011, the countries met with the worst results, which had the highest proportion of stock market securities in their portfolio and was the least pursued a conservative investment policy. So mainly in Bulgaria (-28\%), in Estonia (-17\%), in Belgium, in Poland and in Portugal (equally $-12 \%)$, in Slovakia $(-11 \%)$, in Austria $(-10 \%)$ and in Hungary $(-8 \%)$ it decreased the most actual net return on the pension funds in this four-year period. Before the crisis, in almost all EU Member States, the pension fund's portfolio dramatically increased the share of the stock market instruments. For example, in Bulgaria in 2007 it increased 11-fold in the proportion of listed securities compared to 2003 in the pension funds portfolio, while in Poland four times. But the majority of the 27 EU Member States have at least doubled their share. After the financial and economic crisis, this trend was reversed, and in many countries the proportion of these instruments decreased more than half. The least in Sweden (23\%) and the UK (24\%), while the most in Slovenia (by $78 \%$ ) and Greece (87\% respectively). In general it can be said that European pension funds due to the crisis increasingly began to turn in the direction of safer forms of investment, and therefore the share of government bonds was raised from over $50 \%$ of their assets.

\section{Did Hungary Follow Argentina's Example?}

Several analysts think that Hungary followed in the footsteps of Argentina in terms of restructuring the pension funds system when giving an ultimatum to employees that they could lose their entitlement to state pension unless they step back into the state pension funds system (Equality Law, 2010; Simon, 2010; Simonovits, 2011). According to these analysts' opinions, when Hungary took over the rather significant amount of assets of private pension funds, it followed the example of Argentina, whose government solved the problems arising from the negative consequences of the 2008 global financial crisis by nationalising the 24 billion USD wealth of Argentine private pension funds instead of taking huge loans again. The government of Argentina did so in October 2008, when Hungary was the first in Europe to request help from IMF and took a loan of approximately 25 billion USD in order to avoid bankruptcy. Therefore, those analysts would be right if Hungary had acted the same way as Argentina in order to avoid having to take this extremely huge loan from IMF and the EU. As it can be seen in the Argentine example, the Hungarian government at that time had this opportunity even then. However, it is a fact that if Hungary had chosen the Argentine way in the autumn of 2008, they should not have taken any IMF and EU loans and the debt of Hungary would have been less by 25 billion USD; therefore, the repayment of new loans would have meant significantly less burden for the state budget.

There is another important difference between the two countries, which is that Argentina actually nationalised private pension funds, while Hungary did not. Every member had the option of remaining a member of private pension funds if they wanted to. Even today, there are numerous private pension 
funds operating in the country with a member list of around 70 thousand people. A Hungarian citizen filed a complaint in this matter which the Strasbourg European Human Rights Court dismissed on 13th January 2013 on the grounds that no rights to private property were violated (Hungarian Government - Ministry of Public Administration and Justice, 2013).

\section{Reasons for the Modification of Formerly Mandatory Hungarian Private Pension Funds}

In 2006, Hungarian macroeconomist János Kun drew the attention of the Hungarian government at the time to the fact that the private pension fund system established in Hungary is unprecedented in developed European countries (Kun, 2009). In developed European countries, there were voluntary private pension funds which made payments into the pension funds based on a sectoral agreement, a voluntary decision or a direct agreement with the employer. However, this payment was voluntary from all aspects and was not stipulated by law. Furthermore, it definitely did not result in a loss in the state pension fund. Since the amount of pension received by pensioners did not decrease when mandatory private pension funds appeared, the Hungarian social security system realised a loss in each subsequent year. In the beginning, active employees paid $6 \%$ to private pension funds, which then increased to 7\% from 2003 and 8\% from 2004. These amounts were missing from the pension payments of the given year.

Table 2: Changes of the rules of becoming a member of private pension funds in Hungary

\begin{tabular}{|l|l|l|}
\hline Period & $\begin{array}{l}\text { Mandatory membership of } \\
\text { career-starters }\end{array}$ & $\begin{array}{l}\text { Establishing voluntary } \\
\text { membership }\end{array}$ \\
\hline Before 1st January 1998 & $\begin{array}{l}\text { Establishing membership was } \\
\text { not mandatory }\end{array}$ & $\begin{array}{l}\text { If the conditions set out in PPA* } \\
\text { exist, membership can only be } \\
\text { established voluntarily }\end{array}$ \\
\hline $\begin{array}{l}\text { 1st January 1998- } \\
\text { 31st December 2001 }\end{array}$ & $\begin{array}{l}\text { Establishing membership was } \\
\text { mandatory }\end{array}$ & $\begin{array}{l}\text { Membership can also be } \\
\text { established voluntarily if the } \\
\text { conditions set out in PPA* exist }\end{array}$ \\
\hline $\begin{array}{l}\text { 1st January 2002- } \\
\text { 31st December 2002 }\end{array}$ & $\begin{array}{l}\text { Establishing membership was } \\
\text { not mandatory }\end{array}$ & $\begin{array}{l}\text { If the conditions set out in PPA* } \\
\text { exist, membership can only be } \\
\text { established voluntarily }\end{array}$ \\
\hline $\begin{array}{l}\text { 1st January 2003- } \\
\text { 2nd November 2010 }\end{array}$ & $\begin{array}{l}\text { Establishing membership was } \\
\text { mandatory }\end{array}$ & $\begin{array}{l}\text { Membership can also be } \\
\text { established voluntarily if the } \\
\text { conditions set out in PPA* exist }\end{array}$ \\
\hline 3rd November 2010- & $\begin{array}{l}\text { Establishing membership was } \\
\text { not mandatory } \\
\text { exist, membership can only be } \\
\text { established voluntarily }\end{array}$ \\
\hline 31st December 2011- & $\begin{array}{l}\text { Establishing membership is not } \\
\text { mandatory }\end{array}$ & $\begin{array}{l}\text { Membership can only be } \\
\text { established voluntarily, PPA } \\
\text { does not stipulate any specific } \\
\text { conditions thereto }\end{array}$ \\
\hline
\end{tabular}

* Act LXXXII of 1997 on Private Pensions and Private Pension Funds (PPA) which came into force on 1st September 1997.

Source: PSZÁF (2012) 
Membership fees were deducted from pension fund members' wages by their employers and transferred directly to the given private pension fund in the period between 1st January 1998 and 31st December 2006. Starting from 1st December 2007, employers transferred the membership fees to the tax authorities and they transferred them further to private pension funds. The regulation of the amount of membership fee was included in paragraph 3 of the Act LXXX of 1997 on the Eligibility for Social Security Benefits and Private Pensions and the Funding for These Services.

In Hungary, in the structure established on 1st January 1998, the pension contributions paid by those entering the mixed system were divided. One part of the contribution was not paid into the social security pension system which operated on the basis of the 'pay as you go' principle, but it was credited to and individual fund account as private pension fund membership fee. According to the structure, around one quarter of contributions were paid into private pension funds. Therefore, private pension fund benefits should have covered the social security benefits which were around $25 \%$ lower. According to the 1998 plans, the second pillar would have gradually covered an increasing proportion of members until all of them were covered. Only career starters would have been obliged to enter the system. However, the actual legal regulations made it possible for everyone to freely decide to enter the mixed system until the middle of 1999. Nevertheless, those stepping into the mixed system had to face the fact that their future pension will decrease by $25 \%$ even if they had paid the whole pension contribution into the social security pension funds system before their voluntary entered the mixed system (Magyarorszag Kormanya, 2012, p. 106).

However, the number of people stepping into the mixed system in 19981999 did not live up to the expectations. There were many cases when people decided to enter the mandatory private pension fund system even if it was not a favourable choice for them. The fundamental reason for doing so was the rather single-sided information campaign related to introducing the pension reform, emphasising only the advantages of individual accounts and inheritance and neglecting the risks of entering the mandatory pension fund system. The declared purpose of establishing the funded pension pillar was to contribute to the financeability of the pension system. However, when setting the long-term objective, it should have been taken into consideration that there would be several decades of deficit in the state pension pillar following the introduction of this system. Although part of the contribution of members entering the mixed system was already transferred to their private pension fund accounts, the expense obligations of the state pillar remained unchanged. Extra expenses would have been eliminated only gradually and over a very long time, around 5-6 decades. Following this point of time, the costs saved as a result of lower benefits would have compensated for the deficit. In Hungary, due to the high number of people entering the mixed system, the amount of deficit - the extra burden of the social security pension 
system - significantly increased during a short amount of time. The member list reached $50 \%$ of all insured members even by 2000 , the second year after the introduction of the system and it gradually reached more than $60 \%$ by 2010. The deficit of the 'pay as you go' pension pillar gradually increased as a result of the loss of return and it reached $1 \%$ of GDP by 2004 , while it was close to $1.3 \%$ of GDP by 2009.

The loss arising from contributions transferred to private pension funds was compensated for by the Hungarian state budget to the social security system every yеar. The financial loss arising this way increased from year to year. Based on the reports of the Hungarian Central Administration of National Pension Insurance (2015), the amount of contributions transferred to the mandatory private pension funds was 297495 million HUF in 2007, 330333.2 million HUF in 2008 and 354099.1 million HUF in 2009. The amount of transferred contributions would have been 372380 million HUF in 2010 if the government had not shut down the transfer of contributions to private pension funds and directed them to the state budget. Furthermore, the amount of loss in 2010 would have increased despite the fact that the then government took significant measures to reduce pension expenditures in 2009. The Hungarian mandatory pension funds system caused a nearly 2000 billion deficit to the state budget between 2004 and 2010. Furthermore, the standard of social security services deteriorated, the pensionable age increased and the purchasing power of pensions started to decrease during this period.

Table 3: The Hungarian budgetary deficit (against GDP percentage)

\begin{tabular}{|l|c|c|c|c|c|c|}
\hline & 2005 & 2006 & 2007 & 2008 & 2009 & 2010 \\
\hline $\begin{array}{l}\text { Budgetary deficit } \\
\text { (without private pension funds) }\end{array}$ & 6.79 & 8.14 & 4.21 & 2.15 & 2.79 & 2.71 \\
\hline $\begin{array}{l}\text { Budgetary deficit caused by } \\
\text { private pension funds }\end{array}$ & 1.11 & 1.17 & 0.79 & 1.68 & 1.26 & 1.38 \\
\hline
\end{tabular}

Source: Nagy (2010, p. 11)

The deficit of the Hungarian state budget would have increased further for several years until those not members of private pension funds retire; therefore, they pay their whole pension contributions into the state system and receive their whole pension from the state pillar, while they take their place in the private pension fund members who paid part of their pension contributions into private pension funds. Therefore, this process would have been uninterrupted until all pensioners had been members of private pension funds. According to certain calculations, this process could have lasted until even 2040. Furthermore, the interest of the state debt increasing as a result of the deficit caused by private pension funds burdened the state budget with further hundreds of billions and they would have burdened the budget by further thousands of billions until 2040. 
The average yearly return of mandatory private pension funds was only $0.1 \%$ in the ten-year-long period between December 2001 and December 2010, while the amount of return was negative $(-1.6 \%$ on average) in the five-yearlong period between 2007 and 2011. In the ten-year-long period, the yearly return of private pension funds was $-1.3 \%$ in the United States, $-0.6 \%$ in Spain and $-0.1 \%$ in the United Kingdom. At the same time, the return realised in the same period was only between $0 \%$ and $1 \%$ in three other countries (Hungary $-0.4 \%$, Czech Republic $-0.5 \%$ and Austria - $0.9 \%$ ). In four other countries, private pension funds generated returns of only $1 \%$ or around $1 \%$ between December 2002 and December 2010 (Iceland - 1\%, New Zealand $1.2 \%$, Switzerland $-1.3 \%$ and South Korea $-1.2 \%$ ).

Graph 1: Average annual real net investment return of pension funds in selected OECD countries (Dec 2001 - Dec 2010 and Dec 2007 - Jun 2011)

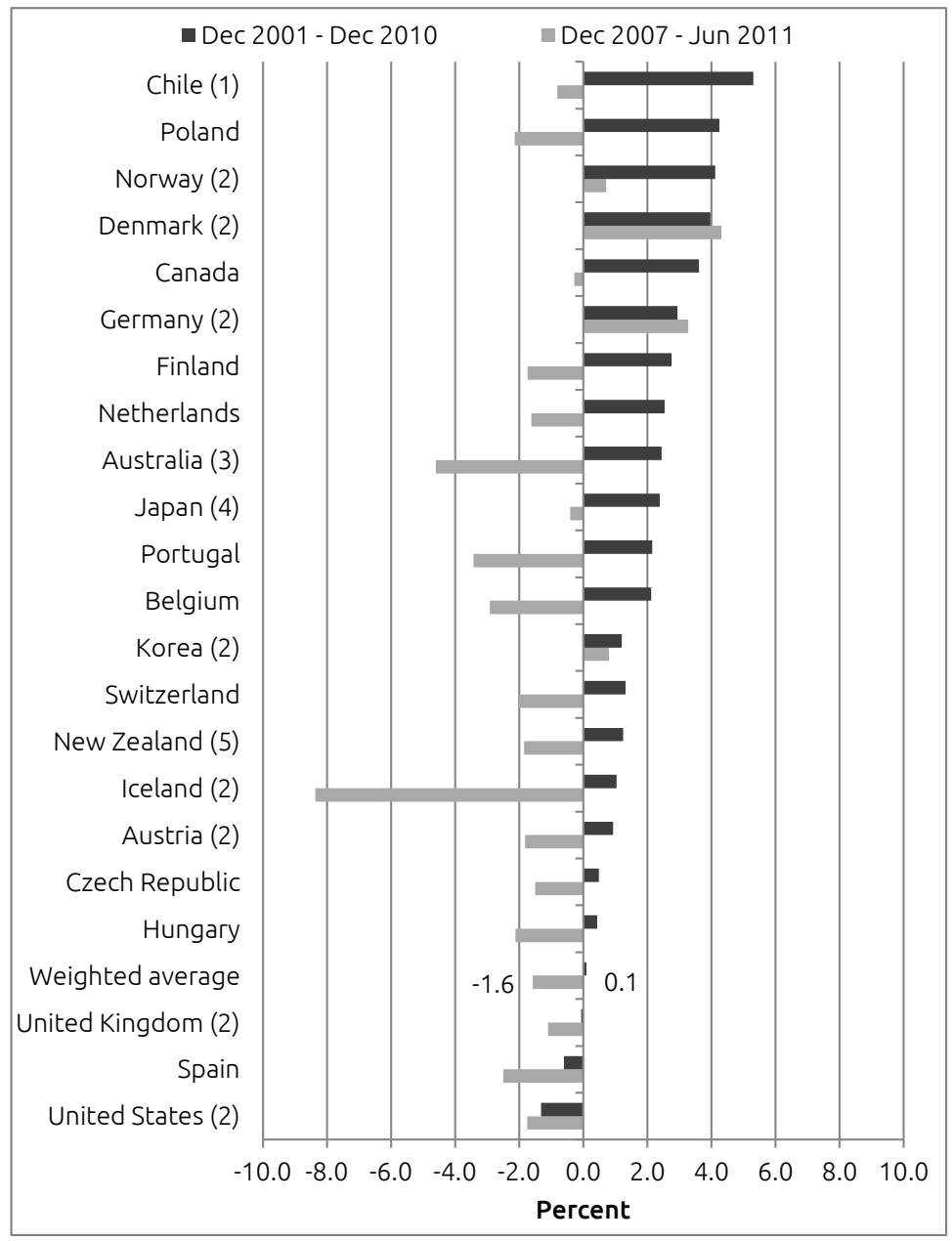

Source: OECD, (2012, p. 21; [Excel file] DOI: 10.1787/888932598113) 
According to the study of EuroFinuse (European Federation of Financial Services Users), the European representative body of people using financial services, these results are especially worrisome in the case of various countries because the OECD did not consider other fees and taxes which further reduce the return of private pension funds. For this reason, the actual return was even lower than reported by OECD (Berthon, Cronin, Prache, Struwe, \& Viver, 2013).

The investment losses have a direct negative impact on the pension income of many pensioners, especially those who take part in a defined contribution (DC) program until their retirement. From month to month, it became obvious in an increasing number of countries that the mandatory private pension funds system was not working as expected. As a matter of course, the unsustainability of this system was first sensed by countries which were highly indebted and/or struggled with a significant deficit in their budget. As a result of the capital market processes in 2008 and 2009, the value of the mandatory private pension funds savings quickly decreased. This practical experience was the opposite of what they had previously heard about the advantages and safety of the mandatory private pension funds system. The members were not given any unambiguous promise for the period until the determination of the amount of pension. As regards future processes, they only had limited guarantee concerning the future increase of savings. This process greatly diminished society's trust in the mandatory private funded pension pillar in Hungary. A significant doubt emerged in a large proportion of pension fund members about whether the savings collected with the mandatory private pension fund system really helped them in establishing the financial background for a decent old age. The decrease of the accumulated savings and the loss of the society's trust happened also in other countries operating the mandatory funded pension pillar.

As the result of a 2009 study, OECD described the high cost level of the Hungarian mandatory private pension funds system as a negative example (OECD, 2009). Of all mandatory pension funds systems, members had to pay the highest administrative and management costs in Hungary, amounting to around $2 \%$ of the wealth managed by the system, while the fees were the lowest in Sweden (less than $0.5 \%$ of the managed wealth). 
Graph 2: Administrative charges in selected OECD and non-OECD countries, 2007 (As percentage of total assets)

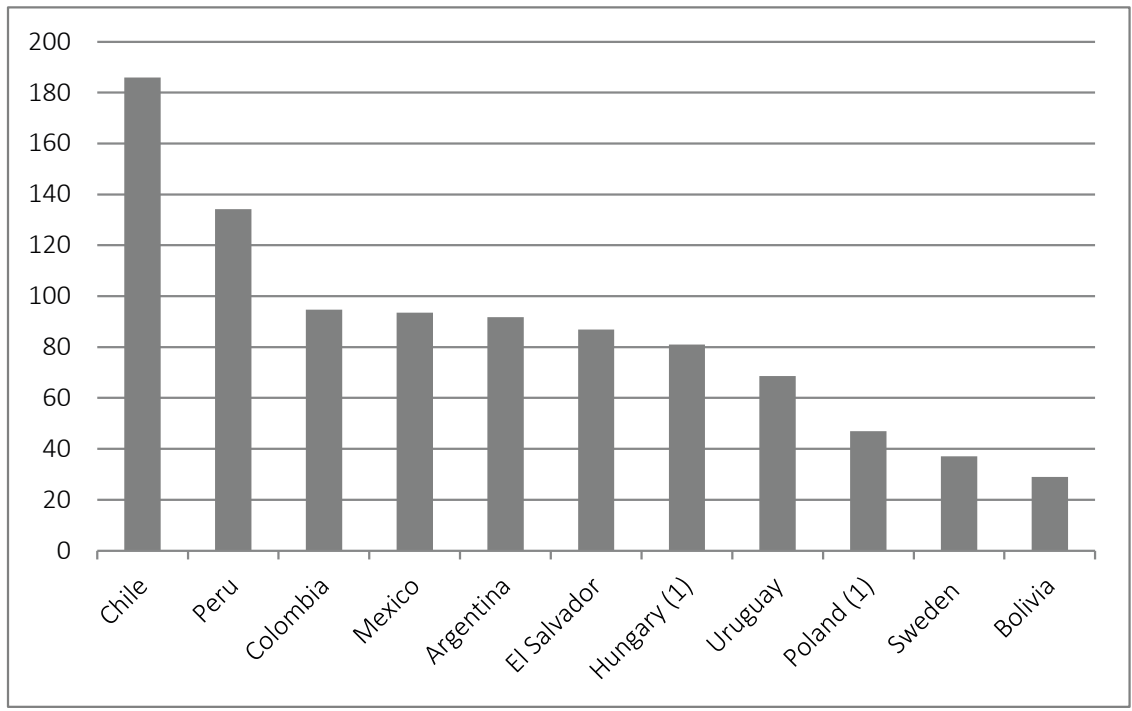

Note: (1) Data refer to the year 2006

Source: OECD (2009, p. 17; [Excel file] DOI: 10.1787/517052344408)

Mostly as a consequence of the above described actions, the return of Hungarian mandatory private pension funds was especially low in the 13-year-long period between 1997 and 2010 and did not even on par with inflation; therefore, it had a negative return. None of the mandatory private pension funds operating in Hungary reached the level the index of short-term government bonds (RMAX), but they were significantly lower. Consequently, Hungarian mandatory private pension fund members would have been better off if these funds had invested the savings of their members into Hungarian government bonds (Magyarorszag Kormanya, 2012, p. 6).

The assumption that the conversion to a capitalised private pension funds system will automatically reduce the evasion of the payment of contributions proved to be wrong. Also, after the drastic reduction of benefits, the issue of maintaining the standard of future benefits gave grounds for serious concern and the measures of the previous governments resulting in the reduction of pensions and their value in real terms further increased these concerns. 
Table 4: Average return of Hungarian private pension funds for 10 and 13 years considering the whole deposit

\begin{tabular}{|c|c|c|c|c|}
\hline & $\begin{array}{l}\text { Nominal } \\
\text { return \% } \\
\text { (10 years) }\end{array}$ & $\begin{array}{l}\text { Nominal } \\
\text { return \% } \\
\text { (13 years) }\end{array}$ & $\begin{array}{l}\text { Real return \% } \\
\text { (10 years) }\end{array}$ & $\begin{array}{l}\text { Real return \% } \\
\text { (13 years) }\end{array}$ \\
\hline Sector total & 5.44 & 5.17 & 0.17 & -0.21 \\
\hline $\begin{array}{l}\text { AEGON Hungary Pension } \\
\text { Fund }\end{array}$ & 4.81 & 4.12 & -0.42 & -1.21 \\
\hline Allianz Hungary Pension Fund & 5.42 & 5.72 & 0.16 & 0.33 \\
\hline $\begin{array}{l}\text { Aranykor National Voluntary } \\
\text { and Private Pension Fund }\end{array}$ & 5.66 & 5.43 & 0.38 & 0.05 \\
\hline AXA Pension Fund & 5.52 & 5.45 & 0.25 & 0.06 \\
\hline $\begin{array}{l}\text { Budapest National } \\
\text { Mandatory Private Pension } \\
\text { Fund }\end{array}$ & 4.24 & 3.83 & -0.98 & -1.52 \\
\hline $\begin{array}{l}\text { Dimenzió Private Pension } \\
\text { Fund }\end{array}$ & 5.98 & 5.81 & 0.67 & 0.35 \\
\hline $\begin{array}{l}\text { Életút First National Pension } \\
\text { Fund }\end{array}$ & 6.88 & 7.26 & 1.52 & 1.72 \\
\hline $\begin{array}{l}\text { Erste Voluntary and Private } \\
\text { Pension Fund }\end{array}$ & 3.81 & 3.56 & -1.36 & -1.66 \\
\hline $\begin{array}{l}\text { Évgyürük Private Pension } \\
\text { Fund }\end{array}$ & 1.70 & 1.49 & -3.39 & -3.70 \\
\hline $\begin{array}{l}\text { Generali Private Pension } \\
\text { Fund (established in 2008) }\end{array}$ & п.а. & п.а. & п.а. & п.а. \\
\hline $\begin{array}{l}\text { Honvéd Voluntary and } \\
\text { Private Pension Fund }\end{array}$ & 3.47 & 3.53 & -1.53 & -1.83 \\
\hline ING Pension Fund & 6.45 & 6.09 & 1.13 & 0.63 \\
\hline MKB Pension Fund & 6.45 & 5.93 & 1.13 & 0.51 \\
\hline OTP Private Pension Fund & 6.21 & 5.86 & 0.90 & 0.44 \\
\hline Postás Private Pension Fund & 6.86 & 6.98 & 1.50 & 1.46 \\
\hline $\begin{array}{l}\text { Quaestor National Private } \\
\text { Pension Fund }\end{array}$ & 3.33 & 2.87 & -1.83 & -2.34 \\
\hline Vasutas Pension Fund & 6.30 & 5.87 & 0.97 & 0.41 \\
\hline $\begin{array}{l}\text { Pension Fund of Electric } \\
\text { Energy Industry Companies }\end{array}$ & 6.28 & 6.57 & 0.96 & 1.09 \\
\hline
\end{tabular}

Source: Kormanyzati Ellenorzesi Hivatal (2011, pp. 45-46)

Today, both internationally renowned financial experts and journalists ask what the point of the whole system is if no positive benefit can be expected from retirement savings (Flood, 2013). 'Not only did the mandatory private pension funds system not solve the problems of the already defective Hungarian pension funds system, but it became another severe social and economic problem itself... The amount of operational costs and unrealised profits is around 850 billion HUF' (Magyarorszag Kormanya, 2012, p. 4).

It also became clear that the solution of problems with demography and low economic activity cannot be postponed or swept under the rug on the pretext of reforming the pension system. These problems must be solved as soon as possible independently of the difficulties of operating the pension funds system. Similarly to all Member States of the European Union, Hungary faces a severe demographic crisis, the estimated life expectancy increased around 
5 years during the last 50 years and it is predicted to increase by 7 years by 2060. In addition to the low number of births, there is a dramatic change of the age composition of the population, resulting in an ageing society. One of the consequences of these phenomena is that the old age dependency ratio will be doubled: currently, the EU average of the amount of people of active age per person above 65 years of age is four (the situation in Hungary is worse), while it is expected to be only two by 2060 (Prugberger \& Barta, 2015). In addition, in the European Union the level of employment was the lowest in Hungary. According to 2010 data, the Hungarian employment level was $8.7 \%$ lower than the EU average. Of the new Member States of the EU, the level of employment increased by nearly $10 \%$ in Bulgaria and by nearly 8\% in Poland between 2002 and 2010, while that of Hungary decreased (by $0.5 \%$ ) in the same period (Novoszath, 2014). For this reason, in 2010, the new Hungarian government declared that they want to solve this problem by focusing the Hungarian economic policy on two areas: increasing employment and stopping population decline (Nemzetgazdasagi Miniszterium, 2011).

By the end of 2010, Hungary faced a dilemma due to the obligation of the EU's mandatory targeted budget deficit of 3.8\% by 2010 and 3\% by 2011 and the constantly increasing deficit caused by private pension funds. Hungary had to choose whether to eliminate and nationalise (similarly to Argentina) second-pillar of pension system or to follow IMF's recipe and the practice of the preceding government and further reduce pensions. However, the Hungarian government chose a third solution by not nationalising the private pension funds, but removing the protective screens of the state from them. As a result, the government does not guarantee private pension funds that their members will benefit even if their private pension funds make unfavourable financial decisions. Private pension funds still had the opportunity to provide above average pensions to their clients, but they lost all state-guarantee and had to fight real market risks. Also, this change made it possible to stop the decrease of the real value of pension in the case of those in the state pillar.

Table 5: Table 5: Change of Hungarian pensions in real terms (percentage)

\begin{tabular}{|l|c|c|c|c|c|c|c|c|}
\hline & 2002 & 2003 & 2004 & 2005 & 2006 & 2007 & 2008 & 2009 \\
\hline $\begin{array}{l}\text { Change of real } \\
\text { income }\end{array}$ & 13.6 & 9.2 & -1.1 & 6.3 & 3.6 & -4.6 & 0.8 & -2.3 \\
\hline $\begin{array}{l}\text { Change of pensions } \\
\text { in real terms }\end{array}$ & 10.0 & 8.6 & 3.3 & 6.3 & 3.0 & -2.2 & 1.8 & -6.4 \\
\hline
\end{tabular}

Source: Hungarian Central Administration of National Pension Insurance (2015, p. 17)

In the majority of cases, retirement is equal to poverty in Hungary. The conditions and consumption possibilities of pensioners are similar to those who have low income from many aspects. In 2010, 650 thousand pensioners lived under the poverty line in Hungary (Zentai, 2010). These people could not heat their homes and eat warm meals. The majority of them were lonely old people living in small villages. They could decide whether to spend on medications and food or turn the heat on. The value of pension in real terms 
reached the 1989 level by 2003. The value of pension in real terms increased between 2004 and 2006, while both income and pension decreased in real terms in 2007. Real income increased by $0.8 \%$ in 2008. In 2009 a result of the reduction and phasing out of the 13th month salary pension in real terms decreased by $6.4 \%$. The decrease of pension was more significant than that of real income.

In the Hungarian economic literature, several theories have emerged with regard to the appropriate directions for pension scheme reform. There was a general consensus that a social element, i.e. a basic pension protected by constitutional law, was necessary; however, incentives should include an element of pension contributions proportional to wages (Rab, 2014). Even until this point of time, private pension funds provided a better service and higher pensions only for people whose income had been above the average. Those who became unemployed and people who had been discriminated in the labour market in the first place (Roma people, those above 50 years of age, women, women with children, disabled people, etc.) or people whose income had been lower in the first place, had to face lower pension. For this reason, more than 60000 people were forced to step back into the state pillar directly before their retirement in late 2009, when this option was available for the first time.

\section{Legislative Changes of the Restructuring of the Hungarian Pension Fund System}

In late 2010, the government discussed the conceptual issues of implementing the pension reform; they reviewed the duties in relation to the free choice of pension funds and agreed to the restructuring of the pension funds system. Government Resolution No. 1281/2010. (XII. 15.) about the conceptual directions of implementing the pension reform and the tasks in relation to the free choice of pension funds, as follows:

- in order to provide financeability in the short, medium and long run, Hungary returns from the three-pillar system to the two-pillar, solidarity and voluntary funded pension system also operated by 18 EU Member States;

- in addition to the state pillar, the voluntary pension insurance funds based on voluntary contribution will be maintained and strengthened;

- relieving the Pension Insurance Fund of non-pension related, but social payments and having these payments managed by the central budget;

- making legislative changes so that pension can only be funded from amounts paid for pension purposes and no other revenues of the budget may be charged for this purpose; also, contributions paid into the social security pension fund can only be spent on pension payments; 
- the expenses of the reform are financed by the merging of the state and semi-state pillars while declaring that other budgetary resources cannot be used for the same purpose.

The possibility of returning to the state pillar was provided even to those who retired before 1st February 2011 and were provided retirement allowance in their own right concerning their membership in private pension funds. Based on the legislative background, previous private pension fund members returning to the social security pension system were provided the real return of their savings for pension purposes or they had the opportunity to transfer this amount to a voluntary pension insurance fund or to an individual account to be established in the social security pension system. The private pension fund members whose real return was negative and returned to the solidarity pillar of the state were provided their whole pension contributions plus inflation as if they had not even left it in the first place.

Act no. CLIV of 2010 established the legislative background of individual accounts in the social security pension system. The rules determined the method of pension system restructuring in detail: the private pension fund members who wanted to maintain their private pension fund membership had to make a declaration. The most accentuated part of the Act was the one which specified that those who did not return to the social security pension system still had to fulfil their obligation to pay contributions to the given private pension fund ( $10 \%$, i.e. the whole amount paid by an employee) after 31st December 2011. According to the plans, the given employee would not have been entitled to pension benefits from the social security pillar, thereby 'contracting out' of the state-funded social security system (as a matter of course, the obtained rights of the employee would not have been infringed upon, i.e., they would still have been entitled to the social security benefits earned up to this point). It was an important element of this Act that it specified a rule which compensated for the 14-month-long suspension of the transfer of private pension fund membership fees: the whole amount of the pension benefits for this period were paid from the state pillar. The freedom of choosing pension funds made it possible for all fund members to step back into the social security pension system. Around 3 million people stepped back into the social security pension system and the Central Administration of National Pension Insurance (ONYF) provided all-inclusive information to the members concerning this action (Nemzetgazdasagi Miniszterium, 2012).

These changes did not affect the third pillar, i.e., the operational frameworks of voluntary mutual pension insurance funds. In addition, the government supported the transfer of real benefits and membership fee supplements into voluntary mutual pension insurance funds with tax allowance.

Both the returning of private pension funds members into the state pillar and the transfer of private pension funds membership fees for 14 months resulted in extra income for the social security pension system, which was 
partially a short-term and also a long-term extra resource. On the one hand, this amount reduced the increasing deficit of the social security pension system, while it was spent on reducing the state debt on the other. The extended scope of budgetary action made it possible to make measures needed for launching economic growth and for providing stable grounds for the Hungarian economy.

As a result of the legislative amendment in late 2011, the possibility of returning to the state pillar was provided to private pension fund members, the number of private pension fund members decreased below 75000.

\section{Conclusions}

The Hungarian pension reform which entered into force on 1st January 1998 significantly contributed to increasing the budgetary deficit and the state debt. One of the main lessons learned from the failure of the partial privatisation of the Hungarian pension funds is that such comprehensive restructuring should not have been performed before preliminary and allinclusive social and economic impact assessment. It is also very revealing that more than 12 years had to pass before this unbelievably unjust and moneywasting system which contributed to the indebtedness of the county could finally be abolished. Restructuring the previous mandatory private pension funds system was an especially significant initial step from the aspect of consolidating the severe financial situation of the country. Debt reduction should be constant and significant and a strong pension system has to be established which is able to provide the necessary protection in the long run in order to maintain the value of pensions in real terms also in the case of future recessions. It is necessary to develop a long-term pension strategy whose implementation calls for the proper tools and the necessary wealth in order to avoid current and future negative economic impacts. The compensation for labour market inequalities and ensuring gender equality is another important issue to be solved. In order to do this, it is important to develop a general pension calculation system which is independent of individual labour market preliminaries, while the realisation of labour market advantages could be performed by the voluntary section in the future. However, in addition to solving short term problems and challenges, the Hungarian pension system will be working in a stable and sustainable way in the long run only if the currently prevailing unfavourable proportion of active and inactive people can be altered drastically in Hungary and if the number of labour market newcomers would permanently surpass the number of those leaving the labour market. Also, the currently declining demographic trend would need to be reversed. None of the Hungarian governments in office before 2010 realised that the extension of employment, the reduction of economic inactivity among the active population and the increasing number of births are the key factors of the growth of the Hungarian economy and the financial stabilisation of the Hungarian pension system. 
Hungary's example confirms that the mandatory private pension system will not automatically solve the problem of aging and will not make the pension system more sustainable. Another important lesson from the studies to take up the case of private or public pension systems is that without adequate and verifiable performance requirements of output growth can not be achieved. A good example of such a performance measurement and evaluation system is the activity of Canadian Public Sector Investment Board where the application provides a variety of customized benchmarks for the Canadian pension fund ongoing value creation (PSP Investments, 2015). The requirement that the management requires the minimum of benchmark levels of performance and only just recognized performance above the benchmark level. It is also an example of this just the other side of the Hungarian mandatory private pension funds because they were not able to over one and a half decades of operation at least bring a minimum contribution to the resources of the contributors, not to the merits.

Peter Novoszath, PhD is an economist and works as an Associate Professor at the Institute of Public Finance, National University of Public Service, Budapest, Hungary. His main research topics are orthodox, new orthodox and unorthodox monetary and fiscal policies, considered in the international context. He teaches State Control, Economic Policy, National and European Public Finances, Shareholder value-added methods and techniques for the effective economy and management of the public service. For the last years he has specially been doing action research on Public Financing and Social Security Financing. 


\section{References}

Act $C$ of 2010 on the free choice of the pension fund.

Act CLIV of 2010 on certain amendments conducting of the Law on Pension Reform and Debt Reduction Fund, and to the free choice of pension fund.

Act LXXX of 1997 on the Eligibility for Social Security Benefits and Private Pensions and the Funding for These Services.

Act LXXXII of 1997 on Private Pensions and Private Pension Funds (PPA).

Barr, N. A. (1979). Myths my Grandpa taught me. Three Banks Review, (124), $27-55$.

Barr, N. A. (2002). Reforming Pensions: Myths, truth and policy choices. International Social Security Review, 55(2), 3-36. DOI: 10.1111/1468-246X.00122

Barr, N. A. (2012). Economics of the Welfare State (5th ed.). London: Oxford University Press.

Berthon, J., Cronin, C., Prache, G., Struwe, K., \& Viver, J. M. (2013). The Real Return of Private Pensions (A Research Report by EuroFinUse). Brussels, Belgium: EuroFinUse. Available at http://www.betterfinance.eu/fileadmin/user_ upload/documents/Research_Reports/en/Pension_Study_EN_website.pdf

Equality Law. (2010, November 30). Hungary Follows Argentina in PensionFund Ultimatum. Retrieved 6. 7. 2013, from http://www.equality-law.co.uk/ news/406/15/Hungary-Follows-Argentina-in-Pension-Fund-Ultimatum/

European Commission. (2010). Green Paper: towards adequate, sustainable and safe European pension systems (COM(2010)365 final). Brussels: European Commission.

European Commission. (2012). White Paper. An Agenda for Adequate, Safe and Sustainable Pensions (COM(2012)55 final). Brussels: European Commission.

European Commission. (2014). The 2015 Ageing Report: Underlying Assumptions and Projection Methodologies (European Economy 8/2014).Brussels: European Commission Directorate-General for Economic and Financial Affairs, Unit Communication and interinstitutional relations. DOI: 10.2765/77578

European Commission. (2016). Fiscal Sustainability Report 2015 (European Economy Institutional Paper 018). Luxembourg: Publications Office of the European Union. DOI: 10.2765/7398

Flood, C. (2013, June 23). Saving for retirement is 'a losing game'. Financial Times. Retrieved 6. 7. 2013, from http://www.ft.com/intl/cms/s/0/c58a8860d99a-11e2-98fa-00144feab7de.html

Government Resolution No. 281/2010 (XII. 15.) on the conceptual directions of implementing the pension reform and the tasks in relation to the free choice of pension funds.

Hungarian Central Administration of National Pension Insurance. (2015). Yearbook of 2014. Budapest: Dunamix Kft. HU. Retrieved 17. 5.2016, from https://www.onyf.hu/m/pdf/Statisztika/ONYF_Statisztikai_Evkonyv_2014.pdf

Hungarian Government - Ministry of Public Administration and Justice. (2013, February 5). Hungary wins lawsuit regarding private pension funds. Retrieved 6. 7. 2013, from http://www.kormany.hu/en/ministry-of-public-administration-andjustice/news/hungary-wins-lawsuit-regarding-private-pension-funds 
Kormanyzati Ellenorzesi Hivatal [Hungarian Government Control Office]. (2011). Ellenőrzési jelentés. A magán nyugdijpénztárak által a Nyugdijreform és Adósságcsökkentő Alapnak átadott portfóliókkal kapcsolatos gazdálkodás jogszerüségének és hatékonyságának ellenőrzése [Control report. Supervising the legality and efficiency of the management of portfolios provided by private pension funds to the Pension Reform and Debt Reduction Fund.] $\mathrm{KEHI}$.

Kun, J. (2009, April 30). A tyúk nem tojik aranytojást. Hogyan takaríthatnánk meg évente 500 milliárd forintot. [The goose will not lay golden eggs. How could we save 500 billion HUF a year?] Népszabadság.

Magyarorszag Kormanya [The Government of Hungary]. (2012). J/8218. számú jelentés a magán nyugdijjpénztárak müködéséröl, jogi hátteréröl, gazdálkodásuk jog-és célszerüségéröl [Report no. J/8218 on the operation and legal background of private pension funds, as well as the lawfulness and expedience of their operation.]. Budapest.

Nagy, V. (2010). A magyar nyugdijirendszer második pillére, a kötelező magánnyugdij pénztári szektor jellemzői [Characteristics of the second pillar of the Hungarian pension system, the mandatory private pension fund sector]. Nemzetgazdasági Minisztérium.

Natali, D., \& Stamati, F. (2013). Reforming pensions in Europe: a comparative country analysis (Working Paper 2013.08). Brussels: European Trade Union Institute.

Nemzetgazdasagi Miniszterium. [Ministry for Hungarian National Economy]. (2011). A nyugdijrendszer átalakitása [Restructuring the pension fund system]. Nemzetgazdasági Minisztérium.

Nemzetgazdasagi Miniszterium [Ministry for Hungarian National Economy]. (2012). Jelentés a Nyugdíjvédelmi megbizott részére a magyarországi nyugdijfolyamatok, az állami nyugdijpillért és a magánnyugdijrendszert érintö változások hátteréről [Report to the Pension protection commissioner about the Hungarian pension processes and the background of the changes of the state pension system and the private pension system] (NGM, 8765.2012).

Novoszath, P. (2014). A társadalombiztositás pénzügyei [Finances of social security]. Budapest: Nemzeti Közszolgálati és Tankönyv Kiadó Zrt.

OECD. (2009). OECD Private Pensions Outlook 2008, Executive Summary. OECD Publishing.

OECD. (2012). OECD Pensions Outlook 2012. OECD Publishing. DOI: $10.1787 / 9789264169401-e n$

PSP Investments. (2015). 2014 Annual Report. Public Sector Pension Investment Board. Retrieved 15. 12. 2016, from http://www.investpsp.ca

Prugberger, T., \& Barta, J. (2015). A foglalkoztatói kiegészítő nyugdíj megszervezésének és finanszírozásának útjai az Európai Gazdasági Térség államaiban és Magyarországon. [Ways of organising and financing employers' supplementary pension in the countries of the European Economic Region and in Hungary]. In Cs. Lentner (Ed.), Adózási pénzügytan és államháztartási gazdálkodás: Közpénzügyek és Államháztartástan II [Taxation finance and state budget management: Public Finances II] (pp. 553-554). Budapest: NKE Szolgáltató Kft.

PSZÁF [Hungary's Financial Supervisory Authority]. (2012). A magán nyugdijpénztárak létrehozásának okai, szabályozásuk és müködésük tapasztalatai [Reasons for establishing private pension funds, experience with their regulation and operation]. 
Rab, H. (2014). Changes in the Fundamental Rights Aspects of the New Hungarian Fundamental Law in the light of the Retirement Pension System, Journal on Legal and Economic Issues of Central Europe, 5(1), 78-83.

Simon, Z. (2010, December 23). Hungary's Credit Rating Cut by Fitch on Budget; Debt Grade Nears 'Abyss'. Bloomberg. Retrieved 7. 6. 2013, from http://www. bloomberg.com/news/2010-12-23/hungary-debt-rating-is-cut-one-level-to-bbbby-fitch-outlook-is-negative.html

Simonovits, A. (2011). The mandatory private pension pillar in Hungary: An obituary. International Social Security Review, 64(3), 81-98.

DOI: 10.1111/j.1468-246X.2011.01404.X

Zentai, L. (2010). A családok szegénysége, avagy létezik-e gyermekszegénység. [Poverty of families, or is there child poverty?] Polgari Szemle, 6(2). 
POVZETEK

\subsection{Strokovni članek}

\section{Glavni razlogi za preoblikovanje madžarskih obveznih zasebnih pokojninskih skladov}

Na splošno je veljalo, da so naložbeni pokojninski sistemi varnejši od dokladnega sistema. V nasprotju s tem je danes znano, da je kriza finančnih in kapitalskih trgov negativno vplivala na obrestne mere, finančno stabilnost različnih skladov socialnega zavarovanja in na razvoj donosov. Posledice so bile zlasti resne za večstebrne pokojninske sisteme in donos pokojninskih sredstev. Glavni namen tega prispevka je prikazati jasen povzetek glavnih dejstev in motivov za prestrukturiranje financiranja socialnega zavarovanja na Madžarskem, ki poteka od leta 2010.

Madžarska pokojninska reforma, ki je začela veljati dne 1. januarja 1998, je bistveno prispevala k povečanju proračunskega primanjkljaja in državnega dolga. Eden od glavnih naukov neuspeha delne privatizacije madžarskega pokojninskega sklada je, da se tako obsežnega prestrukturiranja ne bi smeli lotiti brez predhodne celovite ocene družbenega in gospodarskega učinka.

Po drugi strani se je madžarski pokojninski sistem do zdaj razvijal v tako smer, da obvezni zasebni pokojninski skladi, ki delujejo na podlagi naložbenega sistema, niso mogli rešiti težav, za odpravo katerih so bili vzpostavljeni. Poleg tega so povzročali še dodatne težave. Primer Madžarske potrjuje, da obvezni zasebni pokojninski sistem ne bo samodejno rešil težave staranja in ni poskrbel za večjo vzdržnost pokojninskega sistema. Toda ob reševanju kratkoročnih težav in izzivov bo madžarski pokojninski sistem na dolgi rok deloval stabilno in vzdržno le, če bo mogoče trenutno prevladujoče neugodno razmerje aktivih in neaktivnih ljudi na Madžarskem bistveno spremeniti in če bo število ljudi, ki vstopajo na trg dela, stalno presegalo število tistih, ki ga zapuščajo. Spremeniti bi bilo treba tudi trenutno upadajoče demografsko gibanje. Nobena madžarska vlada pred letom 2010 ni razumela, da so povečanje obsega zaposlovanja, zmanjševanje gospodarske nedejavnosti prebivalstva in povečanje števila rojstev glavni dejavniki za rast madžarskega gospodarstva in finančno stabilizacijo madžarskega pokojninskega sistema.

Raziskava prinaša še en pomemben nauk, kar zadeva primer zasebnih ali javnih pokojninskih sistemov: brez ustreznih in preverljivih zahtev za uspešnost rezultatov rasti ni mogoče doseči. Dober primer takega sistema merjenja in vrednotenja uspešnosti je delovanje kanadskega odbora za pokojninske naložbe javnega sektorja (Public Sector Pension Investment Board), ki zagotavlja vrsto prilagojenih meril uspešnosti za stalno ustvarjanje vrednosti kanadskega pokojninskega sklada. Pogoj je, da vodstvo zahteva vsaj najnižjo raven meril uspešnosti in priznava le uspešnost, ki to raven dosega. Po drugi strani je madžarski obvezni zasebni pokojninski steber dober primer, da brez zahtev za uspešnost poslovanja ni vrednosti za državo in člane pokojninskega sklada. 